\title{
Inhibiting factors produced by lactic acid bacteria. 1.Oxygen metabolites and catabolism end-products
}

\author{
JC Piard *, M Desmazeaud
}

\author{
INRA, Station de Recherches Laitières, Unité de Microbiologie, 78350 Jouy-en-Josas, France
}

(Received 29 April 1991; accepted 7 June 1991)

\begin{abstract}
Summary - Lactic acid bacteria can produce a variety of antimicrobial compounds which may affect both the lactic acid bacteria themselves as well as undesirable or pathogenic strains. In this first section, we describe the biosynthesis, mode of action and activity spectra of these inhibitors. Metabolites of oxygen (hydrogen peroxide and free radicals) exhibit a bacteriostatic or bactericidal activity against lactic or non-lactic flora. When associated with the lactoperoxidase/thiocyanate system, hydrogen peroxide leads to the formation of inhibitory compounds which are bacteriostatic for lactic acid bacteria and bactericidal for Gram-negative bacteria. The antimicrobial activity of organic acids (lactic, acetic and formic) and of $\mathrm{pH}$ are closely linked. It appears that the non-dissociated fraction of these acids is the major inhibitory form. Thus, acetic acid whose $\mathrm{p} K_{\mathrm{a}}$ is higher than that of lactic acid exhibits the highest inhibitory activity. The antimicrobial activities of diacetyl, acetaldehyde and of the $\mathrm{D}$ isomers of amino acids are also described, although their effects are slight in usual lactic fermentations. Bacteriocins are the last type of inhibitory substance produced by some lactic acid bacteria. They will be described in a second section.
\end{abstract}

lactic acid bacteria / oxygen / acidity / diacetyl / acetaldehyde

Résumé - Facteurs inhibiteurs produits par les bactéries lactiques. 1. Métabolites de l'oxygène et produits du catabolisme. Les bactéries lactiques sont capables de produire une variété de produits inhibiteurs dont les effets peuvent se répercuter sur la flore lactique elle-même mais aussi sur les flores indésirables ou pathogènes. Dans cette première partie, nous décrivons les mécanismes d'apparition, les modes d'action et les spectres d'activité de ces inhibiteurs. Les métabolites de l'oxygène (le peroxyde d'hydrogène et les radicaux libres) peuvent avoir des effets biologiques de nature bactériostatique ou bactéricide sur la flore lactique ou non lactique. Le peroxyde d'hydrogène associé au système lactoperoxydase/thiocyanate, catalyse la formation de produits inhibiteurs, bactériostatiques pour la flore lactique et bactéricides pour les bactéries Gram-négative. Les pouvoirs antibactériens des acides organiques et $d u \mathrm{pH}$ sont intimement liés. II semble que la fraction non dissociée de ces acides soit la forme inhibitrice majeure. De ce fait l'acide acétique de $p \mathrm{~K}_{a}$ supérieur au $p K_{a}$ de l'acide lactique, a un pouvoir inhibiteur supérieur. Les activités inhibitrices du diacétyle, de l'acétaldéhyde et des acides aminés de forme isomérique $D$ sont décrites bien que leurs effets soient mineurs dans les fermentations lactiques habituelles. Les bactériocines produites par certaines bactéries lactiques seront décrites dans une seconde revue.

bactérie lactique / oxygène / acidité / diacétyle / acétaldéhyde

* Correspondence and reprints 


\section{INTRODUCTION}

Aside from their fundamental roles in the formation of organoleptic and rheological characters during the transformation of milk to cheese and yogurt, lactic acid bacteria are used and studied for their capacity to inhibit unwanted bacteria, and thus for increasing the shelf-life of the products.

It is known empirically that the decrease of $\mathrm{pH}$ in itself is a factor of fundamental importance in food safety, since it leads to the elimination of unwanted bacteria and even pathogens. This is important since the ecological niches favorable to lactic acid bacteria have high water activity and are rich in nutrients, thus being very favorable for bacteria proliferation. However, the capacity of lactic acid bacteria to effectively inhibit other species not only results from their ability to lower the $\mathrm{pH}$, but depends on the nature of the organic acids that they produce. Also, other antimicrobials such as oxygen metabolites (eg hydrogen peroxide), bacteriocins, diacetyl, acetaldehyde and D isomers of amino acids are likely to enhance the inhibitory activity of lactic acid bacteria.

Renewed interest in these aspects of the metabolism of lactic acid bacteria has occurred. Industrial accidents leading to food poisoning, notably by Listeria monocytogenes have provided the impetus for research on the potential use of lactic acid bacteria to improve food safety and even to create new fermented products.

The present review will deal with current knowledge on the inhibitory potential of lactic acid bacteria. We will also discuss the possible benefit to food safety that could result from better control of these various inhibitory systems.

This section deals with inhibition phenomena due to oxygen metabolites and end-products of catabolism (organic acids,
$\mathrm{pH}$, diacetyl, acetaldehyde, D isomers of amino acids). In the second section, we will examine inhibitions due to small antimicrobial molecules or to bacteriocins. Inhibition resulting from inter-strain competition (Juillard et al, 1987) is not within the scope of this literature review and so will not be discussed.

For convenience, Lactococcus lactis subsp lactis, $L$ lactis subsp lactis biovar diacetylactis and $L$ lactis subsp cremoris will be designated $L$ lactis, $L$ diacetylactis and $L$ cremoris respectively.

\section{OXYGEN METABOLITES}

\section{Mechanism of appearance}

Lactic acid bacteria are called facultative anaerobes, or aerotolerant, and they catabolize sugars via fermentation. This means that electron transport chains do not intervene, but in subsequent oxidoreduction steps nicotinamide adenine dinucleotide (NAD) participates, undergoing cycling oxidation and reduction. In aerobic conditions, these NAD molecules react with oxygen to form hydrogen peroxide $\left(\mathrm{H}_{2} \mathrm{O}_{2}\right)$ or water as a result of the action of various enzymes (table I). The dismutation of endogenous superoxide anions $\left(\mathrm{O}_{2}^{-}\right)$(table I) can also add a slight contribution to the accumulation of $\mathrm{H}_{2} \mathrm{O}_{2}$ by the action of a superoxide dismutase (SOD) present in most lactic acid bacteria (Britton et al, 1978) or as a result of manganese, present in high concentrations $(20-25 \mathrm{mmol} / \mathrm{l})$ in the cytoplasm of bacteria lacking SOD (Archibald and Fridovitch, 1981).

With the exception of several isolated cases (Whittenbury, 1964; Kono and Fridovitch, 1983), lactic acid bacteria lack catalase because they cannot synthesize hemoporphyrins. Thus, lactic acid bacteria can rid themselves of hydrogen peroxide 
Table I. Reactions between lactic acid bacteria and oxygen or oxygen metabolites (after Archibald and Fridovich, 1981; Condon, 1987).

Reactions des bactéries lactiques avec l'oxygène ou ses métabolites (d'après Archibald et Fridovich, 1981; Condon, 1987).

Reactions and catalysing enzymes

Lactic acid bacteria

in which the enzyme

has been identified

$$
\begin{aligned}
& \mathrm{NADH}+\mathrm{H}^{+}+\mathrm{O}_{2} \stackrel{\mathrm{NADH}: \mathrm{H}_{2} \mathrm{O}_{2} \text { oxidase }}{\longrightarrow} \mathrm{NAD}^{+}+\mathrm{H}_{2} \mathrm{O}_{2} \quad \text { Most lactic acid bacteria } \\
& 2 \mathrm{NADH}+2 \mathrm{H}^{+}+\mathrm{O}_{2} \stackrel{\mathrm{NADH}: \mathrm{H}_{2} \mathrm{O} \text { oxidase }}{\longrightarrow} \mathrm{NAD}^{+}+2 \mathrm{H}_{2} \mathrm{O} \quad \text { Most lactic acid bacteria } \\
& \text { Pyruvate }+ \text { phosphate }+\mathrm{O}_{2} \stackrel{\text { pyruvate oxidase }}{\text { TPP, FAD }} \underset{\begin{array}{l}
\text { acetylphosphate } \\
+\mathrm{CO}_{2}+\mathrm{H}_{2} \mathrm{O}_{2}
\end{array}}{\begin{array}{l}
\text { L delbrueckii, } L \text { plantarum } \\
P \text { halophilus, } S \text { mutans }
\end{array}}
\end{aligned}
$$

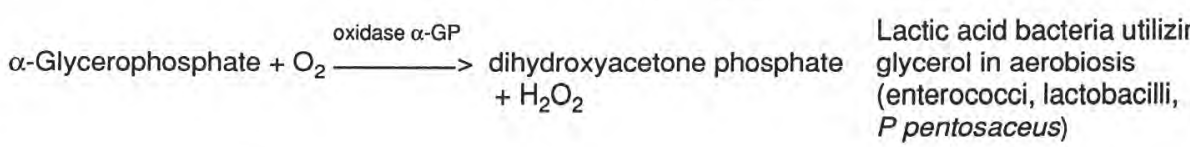$$
2 \mathrm{O}_{2}^{-}+2 \mathrm{H}^{+} \longrightarrow \text { SOD } \quad \text { Most lactic acid bacteria }
$$$$
\mathrm{NADH}+\mathrm{H}^{+}+\mathrm{H}_{2} \mathrm{O}_{2} \stackrel{\mathrm{NADH} \text { peroxidase }}{\longrightarrow} 2 \mathrm{H}_{2} \mathrm{O} \quad \text { Most lactic acid bacteria }
$$$$
2 \mathrm{O}_{2}^{-}+2 \mathrm{H}^{+} \longrightarrow \mathrm{Mn}^{2+} \longrightarrow \mathrm{H}_{2} \mathrm{O}_{2}+\mathrm{O}_{2} \quad \text { Bacteria lacking SOD }
$$

TPP: thiamine pyrophosphate; FAD: flavine adenine dinucleotide; GP: glycerophosphate; SOD: superoxide dismutase.

formed, only by their NADH peroxidase. It follows that the concentration of $\mathrm{H}_{2} \mathrm{O}_{2}$ formed in aerobiosis is variable and depends on the activities of NADH oxidase and $\mathrm{NADH}$ peroxidase, catalyzing the formation and degradation of $\mathrm{H}_{2} \mathrm{O}_{2}$ (Anders et al, 1970).

The simultaneous presence of hydrogen peroxide and superoxide anions can be the origin of hydroxyl radical formation according to the reaction: $\mathrm{O}_{2}^{-}+\mathrm{H}_{2} \mathrm{O}_{2} \rightarrow$
$\mathrm{OH}^{-}+\mathrm{OH}^{\bullet}+\mathrm{O}_{2}$ (Gregory and Fridovitch, 1974). Aerobic growth of lactic acid bacteria thus leads to the formation of 3 principal derivatives of oxygen: $\mathrm{H}_{2} \mathrm{O}_{2}, \mathrm{O}_{2}^{-}$and $\mathrm{OH}^{*}$ which are vectors of "oxygen toxicity".

\section{Mode of action}

Although the toxicity of oxygen has been demonstrated, its modes of action have not been as clearly elucidated. Two types 
may be distinguished, one leading to a bacteriostatic effect, the other being bactericidal.

\section{Bacteriostatic effect}

Homolactic bacteria catabolize glucose via the Embden-Meyerhof pathway, while heterolactic bacteria follow the pentose phosphate shunt. In the case of homolactic fermentation, the 2 molecules of NAD reduced during the formation of glyceraldehyde-3-phosphate (G3P) are reoxidized to favor the reduction of pyruvate to lactic acid by a lactic dehydrogenase (LDH). When the cells are in aerobic conditions, their $\mathrm{NADH}$ oxidase and NADH peroxidase systems are induced (Murphy and Condon, 1984), which compete with LDH for available NADH. This results in a decrease in the acidifying activity of the bacteria. The same reasoning applies to heterofermenting bacteria using the pentose phosphate pathway.

The oxidation of sulfhydryl compounds may have a bacteriostatic or bactericidal effect, depending on whether or not the reaction is reversible when the cells return to anaerobic conditions. The denaturing effect of oxygen and its metabolites on G3P dehydrogenase has been shown (Kong and Davison, 1980) and it is probable that oxidation of sulfhydryl to disulfide affects a number of enzymes (lactate dehydrogenase, alcohol dehydrogenase) or coenzymes with sulfhydryl groups (coenzyme A) (Haugaard, 1968).

The toxicity of oxygen may result from the peroxidation of membrane lipids (Haugaard, 1968), which would explain the increased membrane permeability caused by $\mathrm{H}_{2} \mathrm{O}_{2}, \mathrm{O}_{2}^{-}$and $\mathrm{OH}^{*}$ (Kong and Davison, 1980). This hypothesis was supported by the finding that the degree of membrane lipid peroxidation was related to a loss of viability by $E$ coli (Harley et al, 1978). Once cell envelopes are damaged by the above-mentioned metabolites, the presence of molecular oxygen may reinforce the damage, perhaps by a direct effect at the level of the affected membrane sites.

\section{Bactericidal effect}

Free radicals and hydrogen peroxide can damage bacterial nucleic acids, leading to reversible or irreversible alterations. Ananthaswamy and Eisenstark (1977) demonstrated the modification of DNA by hydrogen peroxide by showing that $E$ coli mutants lacking DNA repair systems were more sensitive to $\mathrm{H}_{2} \mathrm{O}_{2}$ than strains with intact repair systems. Hydrogen peroxide apparently causes breaks in the carbonphosphate backbone of DNA, releasing nucleotides and preventing chromosome replication (Freese et al, 1967).

Hydroxyl radicals can attack the methyl group of thymine, thereby damaging DNA (Byczkowski and Gessner, 1988). Active molecular oxygen can also react with guanine and cause breaks in one strand of DNA. This was shown in $E$ coli, where treatment of plasmid DNA prevented transformation (Di Mascio et al, 1989).

Gram-negative bacteria are better protected from the toxic effect of oxygen metabolites because of the presence of an outer lipopolysaccharide layer. This envelope traps active molecular oxygen (Dahl et al, 1989). Thus, the kinetics of cell death is a multistep process in Salmonella sp (multihit killing), while it is linear in the case of $L$ lactis. Lactic acid bacteria have an additional handicap in the resistance to molecular oxygen because they lack membrane carotenoids. Active molecular oxygen thus diffuses through the peptidoglycan layer rapidly and reacts with sensitive membranes sites (Dahl et al, 1989).

\section{Effect on lactic flora}

The relative toxicity of $\mathrm{H}_{2} \mathrm{O}_{2}, \mathrm{O}_{2}-$ and $\mathrm{OH}^{\circ}$ towards bacteria is somewhat controver- 
sial. Concerning lactococci, there is an apparent consensus that hydrogen peroxide is the major inhibitor (Condon, 1987). Anders et al (1970) reported that 0.2 $\mathrm{mmol} / / \mathrm{H}_{2} \mathrm{O}_{2}$ was the concentration which inhibited the growth of these bacteria by $50 \%$ and that $1.5 \mathrm{mmol} / \mathrm{l}$ induced cell death. Autoinhibition by $\mathrm{H}_{2} \mathrm{O}_{2}$, however, is not universal among lactococci. Thus, Smart and Thomas (1987) showed that in oxygen-insensitive strains, there is an adequateness between the activities of $\mathrm{NADH}: \mathrm{H}_{2} \mathrm{O}_{2}$ oxidase and $\mathrm{NADH}$ peroxidase, preventing the accumulation of hydrogen peroxide. In some strains, reduction of oxygen to water by an $\mathrm{NADH}: \mathrm{H}_{2} \mathrm{O}_{2}$ oxidase enables these bacteria to remain unaffected by aerobiosis.

Although inhibition is occasionally observed in lactobacilli in aerobic conditions, the modes of action remain to be established. It is generally admitted that hydrogen peroxide is not responsible for this inhibition (Gregory and Fridovitch, 1974; Yousten et al, 1975; Condon, 1983). Some authors have advanced the notion that the absence of SOD in Lactobacillus could enable the formation of hydroxyl radicals via a reaction between the superoxide anion and hydrogen peroxide (Gregory and Fridovitch, 1974). The authors attributed the toxicity of oxygen to these $\mathrm{OH}^{*}$ radicals. Subsequently, however, Archibald and Fridovitch (1981) reported that lactic acid bacteria lacking SOD had a dismutation activity resulting from their high $\mathrm{Mn}^{2+}$ levels (see table I). This system protects them from the superoxide anion and prevents the formation of hydroxyl radicals. The authors concluded that inhibition resulted from the combination of several factors (Condon, 1983) or from the shunting of carbohydrate metabolism towards other metabolic pathways where energy production is slower (Murphy and Condon, 1984).

Recent data suggest that lactic acid bacteria can adapt to oxygen. Lactococci sensitive to hydrogen peroxide and exposed to a sublethal concentration of the compound became capable of growth in the presence of a lethal concentration of hydrogen peroxide (Condon, 1987). The author observed the simultaneous induction of NADH peroxidase and, to a lesser extent, that of NADH oxidase. The same induction was shown when cells were subjected to a sublethal temperature, leading the author to suggest that it may be a question of stress proteins. These inductions may partially explain the variability of results presented above.

Similar phenomena have been described in other bacteria. Thus, 30 proteins are induced in Salmonella typhimurium when cells are treated with sublethal doses of hydrogen peroxide (Morgan et al, 1986). Five of these proteins are also induced after a heat shock. Other stresses, such as treatment with nalidixic acid or ethanol, lead to the synthesis of the same 30 proteins, in addition to others. On the other hand, the proteins induced by hydrogen peroxide are not the same as those induced by aerobiosis.

\section{Effect on non-lactic flora}

Among the non-lactic acid bacteria that may be present in milk, it is of interest to note that the catalase + character of unwanted Gram-negative bacteria (Pseudomonas, $E$ coli) does not render them particularly tolerant to oxygen metabolites (Rolfe et al, 1978). Price and Lee (1970) concluded that hydrogen peroxide was responsible for the inhibition of Pseudomonas, Bacillus and Proteus by $L b$ plantarum. Dahiya and Speck (1968) reported that hydrogen peroxide produced by Lactobacillus inhibited Staphylococcus aureus and the optimal $\mathrm{H}_{2} \mathrm{O}_{2}$ production was obtained at $5^{\circ} \mathrm{C}$.

In conclusion, oxygen metabolites may affect both lactic acid flora itself as well as 
unwanted species. Various avenues of investigation are promising for obtaining optimal benefit from the inhibition of these metabolites. The construction of strains containing amplified NADH oxidase systems will lead to excess production of $\mathrm{H}_{2} \mathrm{O}_{2}$. Detailed studies on the mechanisms of resistance to these compounds (notably via stress proteins) should be undertaken in parallel to avoid phenomena of autoinhibition.

\section{THE LACTOPEROXIDASE- THIOCYANATE-HYDROGEN PEROXIDE SYSTEM OF MILK}

The inhibition observed is based on the interaction between three compounds: lactoperoxidase, thiocyanate and hydrogen peroxide. Lactoperoxidase is the name given to milk peroxidase, of which cow's milk contains $10-30 \mu \mathrm{g} / \mathrm{ml}$ (Reiter, 1985). This activity is more than sufficient to activate the lactoperoxidase system (LPS), since Pruitt and Reiter (1985) showed that the reactions of the LPS could be catalyzed by a lactoperoxidase concentration as low as $0.5 \mathrm{ng} / \mathrm{ml}$.

Lactoperoxidase can tolerate an acidity equivalent to $\mathrm{pH} 3$ in vitro (Wright, 1958) and resists human gastric juice (Gothefors and Marklund, 1975). It is relatively heatstable, since it is only partially inactivated by a short pasteurization at $74^{\circ} \mathrm{C}$ (Wright and Tramer, 1958), after which there subsists enough residual activity for the LPS to remain effective.

The thiocyanate anion $\left(\mathrm{SCN}^{-}\right)$is widely distributed in animal secretions and tissues and its concentration is a reflection of eating habits and lifestyle of the individuals (Reiter and Härnulv, 1984). The thiocyanate concentration in milk varies from 1 to $10 \mathrm{ppm}$ and the compound has a dual role in the LPS: it is directly involved in the mechanism of inhibition of the system but also stabilizes lactoperoxidase at high dilutions (Steele and Morrison, 1969).

Native milk does not contain hydrogen peroxide (Reiter and Härnulv, 1984), although it has been observed that milk lactic acid flora (lactococci and lactobacilli) after milking can produce $\mathrm{H}_{2} \mathrm{O}_{2}$ in aerobic conditions, even when the milk is stored at low temperature (Dahiya and Speck, 1968). Saliva taken aseptically from human salivary glands contains hydrogen peroxide (Pruitt et al, 1982).

\section{Mode of action and biological effects}

In the presence of $\mathrm{H}_{2} \mathrm{O}_{2}$, lactoperoxidase catalyzes the oxidation of thiocyanate to non-inhibitory end-products, such as $\mathrm{SO}_{4}{ }^{2-}, \mathrm{CO}_{2}$ and $\mathrm{NH}_{3}$ (Oram and Reiter, 1966). In the course of this oxidation, however, more or less inhibitory intermediates form, eg hypothiocyanate $\left(\mathrm{OSCN}^{-}\right.$) (Aune and Thomas, 1977) or higher oxyacids $\mathrm{O}_{2} \mathrm{SCN}^{-}$and $\mathrm{O}_{3} \mathrm{SCN}^{-}$(Pruitt et al, 1982).

The major effect of these metabolites occurs at the level of the oxidation of sulfhydryl groups of metabolic enzymes (Thomas and Aune, 1978). Thus, hexokinases are totally inhibited, and aldolases and 6-phosphogluconate dehydrogenase are partially inactivated by the LPS. Law and John (1981), however, showed that energy-transducing D-lactate dehydrogenase was also inhibited by this system, even though its active site does not contain $\mathrm{SH}$ groups.

The LPS also causes lesions in the cytoplasmic membrane, causing the leakage of potassium ions, amino acids and polypeptides from the cell. Sugar and amino acid transport systems are also inhibited, as are the synthesis of DNA, RNA and proteins (Reiter and Härnulv, 1984).

As in the case of the direct toxicity of oxygen metabolites, the catalase + charac- 
ter of Gram-negative bacteria confers no advantage on them, and is even detrimental. Marshall and Reiter (1980) showed that the LPS is bacteriostatic for $L$ lactis and bactericidal for $E$ coli (fig 1), which may be due to structural differences in the cell walls. Oram and Reiter (1966) showed that LPS-resistant strains of lactic acid bacteria contained an enzyme which catalyzed the oxidation of $\mathrm{NADH}_{2}$ in the presence of an intermediate product of thiocyanate oxidation. It is thus possible that lactic acid bacteria can neutralize the oxidation products of thiocyanate or else can repair the damage caused (Reiter and Härnulv, 1984).

The LPS has a broad spectrum of activity, including most Gram-negative bacteria found in milk, eg Pseudomonas and E coli (Björck et al, 1975), Salmonella (Purdy et al, 1983) and Shigella (table II). Pruitt and Reiter (1985) published a list of the biological effects caused by the LPS in bacteria.
Among undesirable Gram-positive species, Siragusa and Johnson (1989) showed that the LPS delayed the development of $L$ monocytogenes.

\section{Field of application}

In raw milk, the LPS is a powerful inhibitor from hydrogen peroxide producing strains. In addition, this factor augments the toxicity of $\mathrm{H}_{2} \mathrm{O}_{2}$ by a factor of about 100: active against lactococci at a concentration of 1 $\mathrm{mmol} / \mathrm{l}$ (Anders et al, 1970), hydrogen peroxide present at $10 \mathrm{nmol} / \mathrm{l}$ is sufficient to activate the LPS (Thomas, 1985).

The acid resistance of the LPS and the fact that $\mathrm{SCN}^{-}$arises from raw milk or from the digestion of certain plants led researchers to examine the antibacterial activity of the LPS in vivo. This was shown in calves having absorbed raw milk enriched with $E$ coli: only 1 to $10 \%$ of the strain was found in the abomasum, the fourth (true) stom-
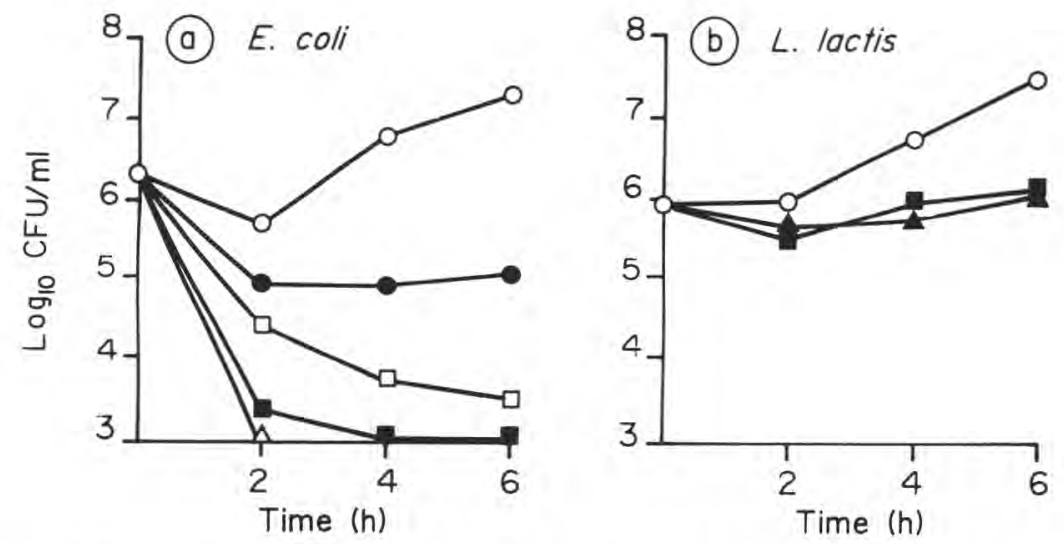

Fig 1. Effect of various concentrations of $\mathrm{OSCN}^{-}$on the viability of $E$ coli (a) and $L$ lactis (b) in synthe-

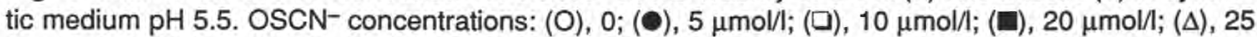
$\mu \mathrm{mol} / \mathrm{l} ;(\mathbf{\Delta}), 35 \mu \mathrm{mol} / \mathrm{l}$ (after Marshall and Reiter, 1980; reprinted by permission of the Society for General Microbiology).

Effet de concentrations variables de OSCN- sur la viabilité de $\mathrm{E}$ coli (a) et de $\mathrm{L}$ lactis (b) dans du milieu synthétique à pH 5,5. Concentrations de OSCN-: (O), 0; (O), $5 \mu \mathrm{mol} / \mathrm{l}$; (口), $10 \mu \mathrm{mol} / \mathrm{l} ;$ (घ), 20

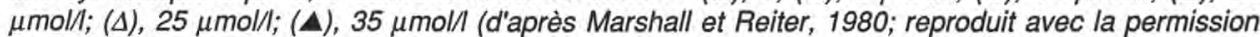
de la Society for General Microbiology). 
Table II. Antibacterial activity of the lactoperoxidase system against various bacteria (after Asperger, 1986; Siragusa and Johnson, 1989). Activité antibactérienne du système lactoperoxydase contre diverses bactéries (d'après Asperger, 1986; Siragusa et Johnson, 1989).

\begin{tabular}{|c|c|c|}
\hline \multirow[t]{2}{*}{ Target strain } & \multicolumn{2}{|c|}{ Biological activity } \\
\hline & $\begin{array}{l}\text { Bacterio- } \\
\text { static }\end{array}$ & $\begin{array}{c}\text { Bacteri- } \\
\text { cidal }\end{array}$ \\
\hline \multicolumn{3}{|l|}{ Lactic acid bacteria } \\
\hline Lactococcus sp & $x$ & \\
\hline Thermophilic lactobacilli & $x$ & \\
\hline \multicolumn{3}{|l|}{ Spoilage bacteria } \\
\hline Pseudomonas fluorescens & & $x$ \\
\hline Gram-negative bacteria & & $\mathrm{x}$ \\
\hline Bacillus cereus & $x$ & \\
\hline \multicolumn{3}{|l|}{ Pathogenic bacteria } \\
\hline Staphylococcus aureus & & $\mathrm{x}$ \\
\hline Escherichia coli & & $x$ \\
\hline Salmonella sp & & $x$ \\
\hline Pseudomonas aeruginosa & & $x$ \\
\hline Listeria monocytogenes & $x$ & \\
\hline
\end{tabular}

ach of ruminants, whereas if one of the components of the LPS system was neutralized, the number of viable coliform bacteria was maintained (Reiter and Härnulv, 1984).

The safety of this system towards eukaryotic cells remained to be shown. Reiter and Härnulv (1984) reported that the LPS did not change the respiration of liver cells in vitro and did not cause lysis of erythrocytes. Hänström et al (1983) even showed that the LPS protected human cells from hydrogen peroxide toxicity.

The LPS is thus a valuable system for some authors, who suggested improving the storage properties of raw milk by adding traces of $\mathrm{SCN}^{-}(12 \mathrm{ppm})$ and $\mathrm{H}_{2} \mathrm{O}_{2}(8$ ppm) (Reiter and Härnulv, 1984). This practice led to a reduction in the undesirable flora of raw milk, especially Pseudomonas $\mathrm{sp}$, whose proteolytic and lipolytic activities pose an important problem when processing milk.

The LPS has been used in pharmacology by incorporating the ingredients necessary to activate the system in toothpastes or contact lens solutions. This system will undoubtedly be developed in the future in the food and agriculture industry. The LPS is a very interesting system in this field, since it is bactericidal for Gram-negative bacteria and only bacteriostatic for Grampositive species. Whenever we speak of a bacteriostatic effect, it is almost certainly a saturable system. Its use to improve the storage of raw milk thus should not have major effects on the subsequent growth of lactic starters. It is also to be noted that if the milk is pasteurized before processing, a part of the lactoperoxidase is inactivated.

\section{END-PRODUCTS OF CATABOLISM}

\section{End-products of carbohydrate catabolism, effect of $\mathrm{pH}$}

The production of acids by lactic acid bacteria contributes to energy production in this bacterial group, as we will see below. The acidity which forms is detrimental for the development of unwanted bacteria and thus greatly improves the hygienic quality of dairy products. However, this acidity can also affect the lactic flora itself. It is to be remembered that the dairy industry most often uses mixed cultures of lactic acid bacteria whose composition is more or less known with certainty. A different acidifying activity and a different acid tolerance of the strains composing the starter may lead to the dominance of the more acidresistant strains. 


\section{Bioenergetics in lactic acid bacteria}

Bacteria have 2 mechanisms for generating ATP:

- phosphorylation of ADP to ATP via glycolysis intermediates;

- chemosmotic energy characterized by a proton gradient.

The latter pathway functions by the presence of the following secondary transport systems:

- coupling of lactate efflux and protons (fig 2 ) in the ratio of $2 \mathrm{H}^{+} /$lactate (Konings, 1985);

- coupling between the entry of solutes and the influx of protons at 1 or $2 \mathrm{H}^{+} /$solute molecule.

Finally, the ATPase system leads to the expulsion of protons with energy consumption $\left(1 \mathrm{~mol}\right.$ ATP/ $\left./ \mathrm{H}^{+}\right)$or the entry of protons with energy production.

During glycolysis, the coupling of lactate and protons efflux creates an electric potential (negative in the intracellular compartment) and a $\mathrm{pH}$ gradient (alkaline in the cytoplasm), whose resultant is the proton motive force (pmf) which generates ATP via the ATPase system (fig 2). This system offers a positive energy balance to lactic acid bacteria during a part of their growth phase. Each molecule of glucose consumed leads to the formation of 2 molecules of lactate. During their excretion, they enable the bacterium to extrude 4 protons. When we subtract the 2 protons resulting from glucose catabolism, the efflux of lactate leads to the translocation of 2 protons per glucose molecule. If they are utilized by the ATPase system, they enable the synthesis of 1 molecule of ATP, which is an energy gain of $50 \%$ in comparison to the 2 molecules of ATP produced by phosphorylation during glycolysis in homofermenting bacteria (Ten Brink and Konings, 1982).

\section{Osmoregulation and regulation} of intracellular $\mathrm{pH}$ in lactic acid bacteria

Lactic acid, the final major product of carbohydrate catabolism by lactic acid bacteria is in equilibrium according to the reaction:

$$
\begin{aligned}
& \mathrm{CH}_{3}-\mathrm{CHOH}-\mathrm{COOH}+\mathrm{H}_{2} \mathrm{O} \\
& \mathrm{CH}_{3}-\mathrm{CHOH}-\mathrm{COO}-+\mathrm{H}_{3} \mathrm{O}^{+}
\end{aligned}
$$

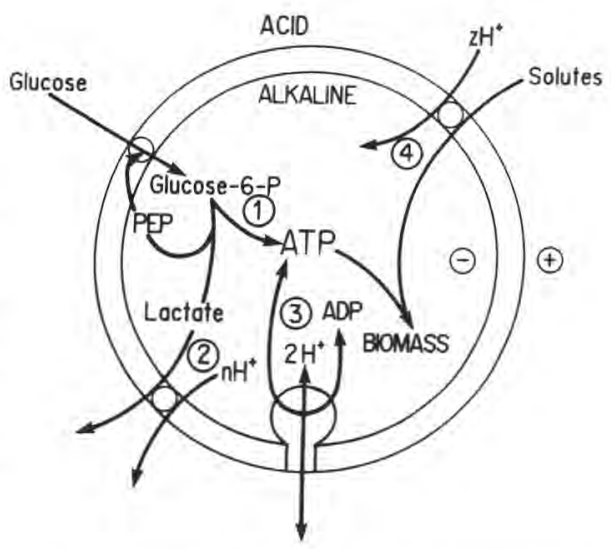

Fig 2. Scheme of metabolic energy-generating and energy-consuming processes in lactococci (after Konings and Otto, 1983; reprinted by permission of Kluwer Academic Publishers). Four pathways related to bioenergetics of the cell are shown: 1) ATP synthesis via glycolysis; 2) the coupling of lactate and protons efflux; 3) the coupling of protons influx or efflux with respectively concomitant ATP synthesis or consumption; 4) the coupling of solutes and protons influx.

Schéma du processus de synthèse et d'utilisation de l'énergie chez les lactocoques (d'après Konings et Otto, 1983; reproduit avec la permission de Kluwer Academic Publishers). Quatre voies liées à la bioénergie cellulaire sont représentées : 1) la synthèse d'ATP par l'intermédiaire de la glycolyse; 2) le couplage des efflux de lactate et de protons; 3) le couplage des influx ou des efflux de protons avec respectivement, synthèse d'ATP ou consommation d'ATP; 4) le couplage des influx de solutés et de protons. 
Since its $\mathrm{p} K_{\mathrm{a}}$ is 3.86 and the initial intracellular $\mathrm{pH}$ is close to neutrality, most lactic acid is ionized. The bacteria must thus face 2 situations: eliminate the proton supply in order to maintain intracellular $\mathrm{pH}$ $(\mathrm{pHc})$ at a value consistent with vital metabolic processes, and eliminate excess lactate in order to restore osmotic balance.

Konings and Otto (1983) determined the factors governing these regulations in cultures grown at uncontrolled $\mathrm{pH}$. Bacterial growth is characterized by the presence of a lactate gradient ( $\Delta$ lact) which causes a $\mathrm{pH}$ gradient $(\Delta \mathrm{pH})$ as a result of $\mathrm{H}^{+}$efflux/lactate coupling '(fig 3 ). This intervenes at the level of the pmf, which simultaneously increases. As cell growth continues, the external lactate concentration increases, $\Delta$ lact and thus $\Delta \mathrm{pH}$ and $\Delta \mathrm{p}$ decrease. This drop in the pmf leads to decreases in both the absorption of nutrients and $\mathrm{H}^{+}$/ lactate stoichiometry. The cell is thus forced to gradually tap its energy reserves to eliminate $\mathrm{H}^{+}$with the ATPase system. Cell death occurs when the cell no longer has energy available to control its $\mathrm{pHc}$.

In cultures run at controlled $\mathrm{pH}$, there is no $\mathrm{pH}$ gradient and the pmf reflects only the difference in membrane potential, ie it is constant during growth and decreases when the sugar in the medium is consumed. Note than in a controlled $\mathrm{pH}$ culture, there is no cell death, and so a pmf will reappear if the bacteria once again have an available carbon source (Konings and Otto, 1983).

The absence of a proton gradient in controlled $\mathrm{pH}$ cultures means that the pmf will have a lower value during the exponential phase of growth. As a result, the growth rate will be lower than in the case of a culture at uncontrolled $\mathrm{pH}$. This phenomenon has apparently not been reported, probably because it is transitory and growth rate calculations are generally made over the entire exponential phase of growth.

\section{Effects of end-products} of sugar catabolism on different flora

\section{Effect on lactic acid bacteria}

At uncontrolled $\mathrm{pH}$, acidification and the decrease of intracellular $\mathrm{pH}$ can lead to decreased activity of metabolic enzymes, even their denaturation, as reported eg by Accolas et al (1980) for the hexokinase of

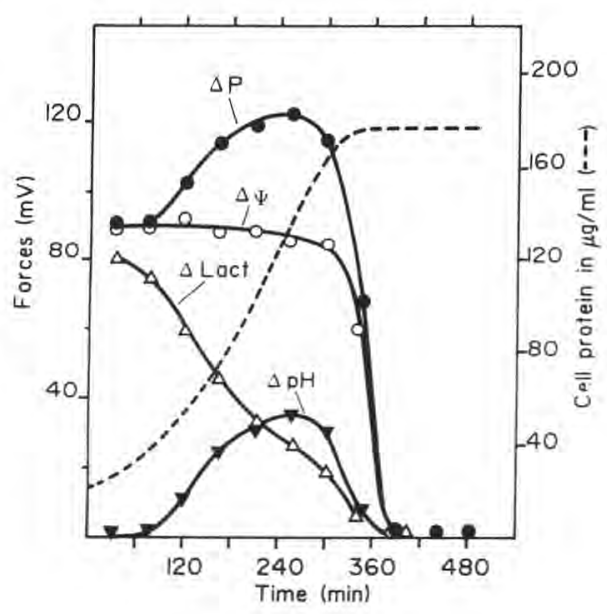

Fig 3. Evolution of proton motive force and of the lactate gradient in $L$ cremoris during growth in batch cultures on complex medium with lactose $(2 \mathrm{~g} / \mathrm{l})$ as sole energy source. (๑), proton motive force; (O), membrane potential; $(\Delta)$, lactate gradient; ( $\mathbf{\Delta}) \mathrm{pH}$ gradient; (---), cell protein concentration (after Konings and Otto, 1983; reprinted by permission of Kluwer Academic Publishers).

Évolution de la force proton motrice et du gradient de lactate au cours de la croissance de $\mathrm{L}$ cremoris en culture discontinue dans un milieu complexe avec le lactose (2 g/l) comme seule source d'énergie. (๑), force proton motrice; $(O)$, potentiel membranaire; ( $\Delta)$, gradient de lactate; (ム), gradient de $\mathrm{pH}$; (--) concentration de protéines cellulaires (d'après Konings et Otto, 1983; reproduit avec la permission de Kluwer Academic Publishers). 
$S$ thermophilus. The tolerance of metabolic enzymes and of transport systems to acid $\mathrm{pH}$ is variable depending on the strain, which could explain the variable acid tolerance in lactic acid bacteria which in mixed cultures leads to phenomena of dominance. Thus, Accolas et al (1977) reported that at uncontrolled $\mathrm{pH}, \mathrm{L}$ bulgaricus continued to grow after $S$ thermophilus stopped growing, while at controlled $\mathrm{pH}$, both strains stopped at the same time (Juillard et al, 1987).

Homofermenting lactic acid bacteria produce lactic acid from glucose in almost stoichiometric quantities. When the bacteria are nutritionally deprived, however, their metabolism also yields formic and acetic acids and ethanol (Cogan et al, 1989). Heterofermenting bacteria degrade glucose to lactic acid, ethanol, $\mathrm{CO}_{2}$ and in some cases acetic acid. The cell membrane is impermeable to ionized hydrophilic acid, while non-ionized hydrophobic acids diffuse passively (Kashket, 1987). Weak organic acids, such as acetic acid ( $\mathrm{p} K_{\mathrm{a}}=4.74$ ) will thus be present at the same concentration on both sides of the membrane. The intracellular medium is basic in comparison to the external medium and will favor the ionization of these molecules and thus an increase in their intracellular concentration. This causes not only an acidification of the cytoplasm, but also the creation of inhibitions, especially of enzymes, by salt excesses. Finally, Kashket (1987) reported that the organic acids and alcohols produced could act as protonophores in the membrane and accentuate the anarchic entry of protons. There are considerable knowledge gaps in this field: although lactic acid bacteria have been extensively studied during their growth, relatively little is known about their behavior in stationary or declining phase.

\section{Effect on non-lactic flora}

There are very few non-lactic bacteria capable of growing at $\mathrm{pH}$ values lower than the threshold $\mathrm{pH}$ of lactic acid bacteria (table III). Good lactic acidification should thus inhibit the growth of $E$ coli, Pseudomonas, Salmonella and Clostridium.

Although it is very easy to determine the $\mathrm{pH}$, this parameter is not a reliable indicator for presuming whether or not microorganisms will develop. The $\mathrm{pH}$ is only a partial illustration of the concentration of weak acids in a medium, since a large part of

Table III. Limit $\mathrm{pH}$ values allowing the initiation of growth of various microorganisms (after Gray and Killinger, 1966; Stadhouders and Langeveld, 1966; Asperger, 1986).

Valeurs de $\mathrm{pH}$ limites permettant l'initiation de la croissance de divers microorganismes (d'après Gray et Killinger, 1966; Stadhouders et Langeveld, 1966; Asperger, 1986).

\begin{tabular}{lc}
$\begin{array}{l}\text { Gram-negative } \\
\text { bacteria }\end{array}$ & $\begin{array}{c}\text { Limit } \\
\mathrm{pH}\end{array}$ \\
\hline & \\
Escherichia coli & 4.4 \\
Klebsiella pneumoniae & 4.4 \\
Proteus vulgaris & 4.4 \\
Pseudomonas aeruginosa & 5.6 \\
Salmonella paratyphi & 4.5 \\
Salmonella typhi & $4.0-4.5$ \\
Vibrio parahaemolyticus & 4.8
\end{tabular}

Gram-positive

Bacillus cereus

Clostridium botulinum $\quad 4.7$

Enterococcus sp

Lactobacillus sp

Micrococcus sp

Staphylococcus aureus

Lactococcus lactis

Brevibacterium linens

Listeria monocytogenes
4.8

$3.8-4.4$

5.6

4.0

$4.3-4.8$

5.6

5.5 
these compounds may be non-dissociated as a function of $\mathrm{pH}$. We saw above, however, that in the case of weak organic acids, it is precisely this non-dissociated fraction that diffuses across the membrane and is more or less ionized depending on intracellular $\mathrm{pH}$. This type of molecule exerts a shadowy effect which cannot be determined by only measuring the $\mathrm{pH}$ of the medium. In this context, the study by Chung and Goepfert (1970) is interesting, since it showed that salmonellas are inhibited at $\mathrm{pH}$ values $<4.4$ for lactic acid and 5.4 for acetic acid. In light of the respective $\mathrm{p} K_{\mathrm{a}}$ values of 3.86 and 4.75 for the 2 acids and of their dissociation constant, inhibition apparently occurs when the nonionized fraction reaches about 20\%. Daly et al (1972) showed that $L$ diacetylactis could inhibit a wide range of unwanted bacteria in dairy products. Using $S$ aureus as the model strain, the authors established that the inhibitory activities of acetic and lactic acids increased as the $\mathrm{pH}$ decreased. Adams and Hall (1988) investigated the individual and cumulated effects of lactic and acetic acids towards $E$ coli and Salmonella enteritidis. They confirmed that the molecular form of these 2 acids is the toxic factor for the bacteria (fig 4). They attributed the higher toxicity of acetic acid to the fact that its $p K_{a}$ is higher than that of lactic acid. The authors also showed that the 2 acids acted synergistically in weakly-buffered media: lactic acid decreased the $\mathrm{pH}$ of the medium, thereby increasing the toxicity of acetic acid.

Several research groups have examined the inhibitory capacity of lactic acid bacteria in terms not only of the growth of sporulated bacteria, but also towards the spores of these bacteria. Thus, Wong and Chen (1988) showed that Bacillus cereus is first progressively inhibited and then killed when cocultured with various lactic acid bacteria. They showed that growth completely stopped at $\mathrm{pH}$ values of 6.1 ,
6.0 and 5.6 in the case of acetate, formate and lactate, respectively, and attributed the major inhibitory power to acetate. In terms of spore germination, the same authors cited, in order, formate, lactate and acetate which inhibited spore germination by $50 \%$ at $0.1 \mathrm{~mol} / \mathrm{l}$ and at $\mathrm{pH} 4.4,4.3$ and 4.2 , respectively. The cumulated effects of the 3 acids were not studied, however, even though they may be produced simultaneously in certain conditions of the growth of lactococci (Cogan et al, 1989).

Concerning other sporulated bacteria, especially Clostridium tyrobutyricum which is responsible for the late blowing of cheeses, a review by Blocher and Busta (1983) indicated that vegetative cells were inhibited at $\mathrm{pH} 4.65$, while spore germination was affected at $\mathrm{pH}$ 4.6.

Finally, it is to be noted that the sensitivity of bacteria to acids depends on variations which in turn depends on the simultaneous action of other factors (salt levels, activity of water, redox potential, heat treatment, etc). For example, Kleter et al (1984) showed the synergy between acidity and the $\mathrm{NaCl}$ concentration in the inhibition of C tyrobutyricum.

In conclusion, it is important to note the high inhibitory capacity of organic acids in the molecular (non-ionized) form. It is consistent to imagine several improvements for the more efficient utilization of this system. Improved acid and salt tolerance of the enzymes of lactic acid bacteria would enable the lactic flora to more efficiently compete with unwanted bacteria. As in the case of the induced resistance to hydrogen peroxide, a more thorough understanding of the stress proteins of lactic acid bacteria could indicate interesting prospects in this field. It would also be of interest to design lactic acid bacteria which at the proper time would switch their catabolism to heterofermenting pathways in order to profit from the high inhibitory power of acetic acid at low $\mathrm{pH}$. 


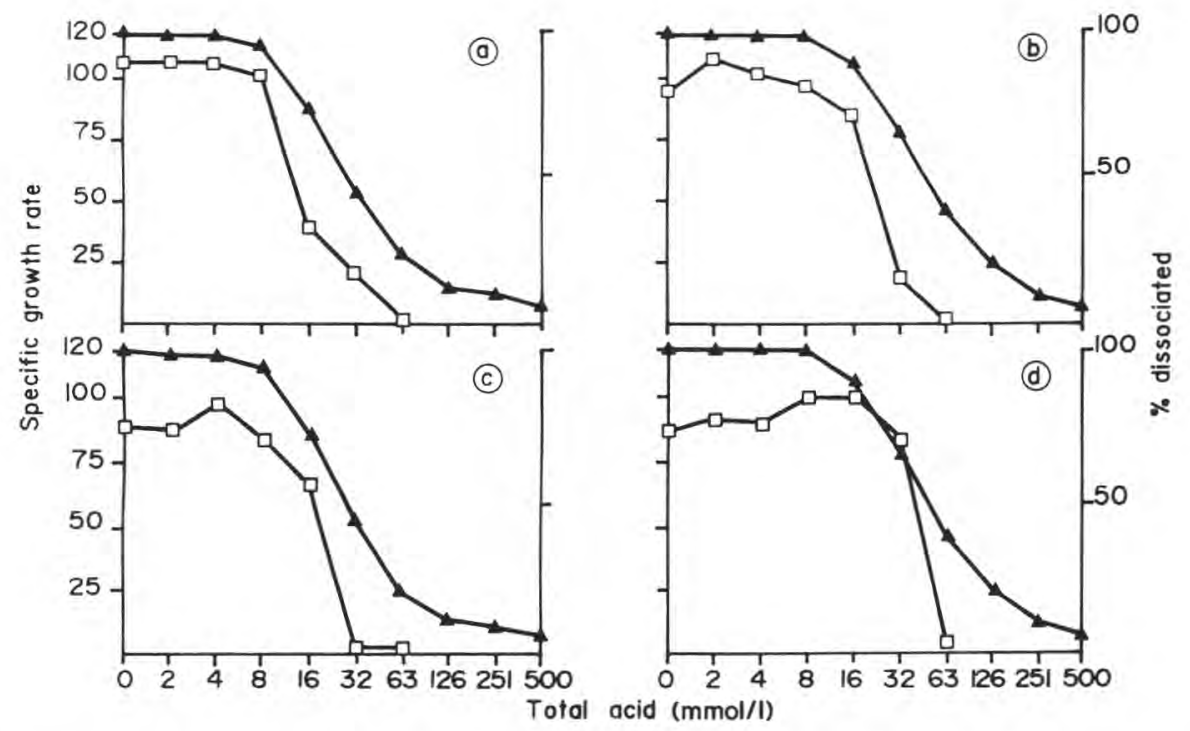

Fig 4. Effect of total acid concentration on microbial specific growth rate ( $\square$ ) and \% dissociation of acid (A). (a) E coli and acetic acid, (b) E coli and lactic acid, (c) Salmonella enteritidis and acetic acid, (d) Salmonella enteritidis and lactic acid. Specific growth rate units are expressed on an arbitrary scale (after Adams and Hall, 1988; reprinted by permission of International Journal of Food Science and Technology).

Effet de la concentration totale d'acide sur le taux de croissance bactérien spécifique (口) et sur le \% de dissociation de l'acide ( $\mathbf{\Delta}$ ). (a) E coli et acide acétique, (b) E coli et acide lactique, (c) Salmonella enteritidis et acide acétique, (d) Salmonella enteritidis et acide lactique. Les unités de taux de croissance spécifique sont exprimées sur une échelle arbitraire (d'après Adams et Hall, 1988; reproduit avec la permission de International Journal of Food Science and Technology).

\section{Diacetyl}

$L$ diacetylactis and Leuconostoc sp can use citrate present in milk $(\approx 8.3 \mathrm{mmol} / \mathrm{l})$. Among the products formed during this metabolism (Cogan, 1980), diacetyl is important since it is the major aromatic constituent of butter and fresh cheeses.

The antibacterial properties of diacetyl have been shown in a large number of studies involving different microorganisms. Jay (1982) published a thorough table of the inhibitory capacity of diacetyl, showing that lactic acid bacteria are insensitive to diacetyl up to the dose of $350 \mu \mathrm{g} / \mathrm{ml}$. Gram-negative bacteria, on the other hand, begin to be inhibited at $100 \mu \mathrm{g} / \mathrm{ml}$ and are almost totally inhibited at $200 \mu \mathrm{g} /$ $\mathrm{ml}$. The author indicated that diacetyl is lethal for Gram-negative bacteria and only bacteriostatic for Gram-positive bacteria.

The mean diacetyl concentration produced by $L$ diacetylactis in pure culture or in coculture with Leuconostoc is $4 \mu \mathrm{g} / \mathrm{ml}$ (Cogan, 1980) and so there is little chance that the compound is antibacterial in lactic fermentations, but it could act synergistically with other factors (Gilliland, 1985). In 
light of the value of the broad spectrum of antibacterial action of diacetyl, especially against Gram-negative bacteria, Jay (1982) suggested its use in manufacturing processes in the food and agriculture industry, as an aseptic agent for surfaces and utensils. Its volatility would avoid contaminating the flavor of the manufactured products. In addition, work is currently under way to construct hyperproducing diacetyl bacteria. The use of these strains could reinforce the antagonist role of diacetyl. Uncertainties remain, however, concerning the mutagenic potential of diacetyl (Jay, 1982).

\section{Acetaldehyde}

Acetaldehyde production in certain dairy products and notably in yogurt, where it is the principal aromatic constituent, is attributed principally to $L$ bulgaricus. This species contains a threonine aldolase which cleaves threonine into acetaldehyde and glycine (Accolas et al, 1980). The flora of yogurt ( $L$ bulgaricus and $S$ thermophilus) cannot metabolize acetaldehyde and so it accumulates in the product at a concentration of $\approx 25 \mathrm{ppm}$ (Accolas et al, 1980).

The possible inhibition of lactic acid bacteria by acetaldehyde is relatively undocumented, limited to the work of Kulshrestha and Marth (1975), who showed that the lactic acid bacteria tested ( $L$ lactis, $L$ citrovorum, $S$ thermophilus) were very slightly inhibited at acetaldehyde doses starting at $10 \mathrm{ppm}$, reaching $3-10 \%$ inhibition at $100 \mathrm{ppm}$. The growth of undesirable bacteria in dairy products, eg Staphylococcus aureus, Salmonella typhimurium or E coli decreased at acetaldehyde concentrations of $10-100 \mathrm{ppm}$. It is also to be noted that cell division of $E$ coli is inhibited by $10^{-3} \mathrm{~mol} / \mathrm{l}$ ( $44 \mathrm{ppm}$ ) acetaldehyde (Egyud, 1967). These data are to be compared with the level of $25 \mathrm{ppm}$ of acetaldehyde produced in yogurt, suggesting that the compound could play a role, undoubtedly minor but not negligible, in antagonism among different flora.

\section{D-isomers of amino acids}

Gilliland and Speck (1968) reported that a compound present in the supernatant of a lactic starter culture inhibited the same starter. The compound was identified as Dleucine, inhibitory at the concentration of 1 $\mathrm{mg} / \mathrm{ml}$. Teeri (1954) showed that several Damino acids inhibited lactobacilli.

The mechanism of these inhibitions has not been elucidated. The initial idea was that D-amino acids compete with L-forms, essential for the growth of lactic acid bacteria. Another hypothesis is that D-amino acids are accidentally incorporated in proteins, rendering them inactive (Gilliland and Speck, 1968).

The conditions for the appearance of $D$ amino acids are unknown. Even though some bacterial antibiotics contain D-amino acids, there is to our knowledge no proof of the presence of a racemase in lactic acid bacteria. This subject requires further study, all the more so since unwanted bacteria such as Pseudomonas are also apparently sensitive to $\mathrm{D}$-amino acids (Daniels, 1966).

\section{CONCLUSION}

The first part of this review has examined the wide range of inhibitory substances in lactic acid bacteria resulting from the metabolism of oxygen and from other catabolic pathways. These inhibitors are only very partially used in the fight against undesirable flora. Future applications are nevertheless promising.

We have seen that the lactoperoxidasethiocyanate-hydrogen peroxide system is a 
powerful inhibitor, capable of exerting a bactericidal effect on a number of pathogens. This system is understood to a sufficient extent to be used and optimized at the pilot scale for the preservation of milk. More detailed studies on the mechanism of resistance to this system by lactic acid bacteria are necessary to envision its use in lactic fermentations.

Inhibitions resulting from oxygen metabolism remain poorly elucidated. There exists a wide variability of sensitivity to these compounds among lactic acid bacteria and this variability is of value when studying the mechanisms involved in the resistance to these metabolites. Stress proteins are apparently involved and more detailed knowledge of these phenomena could have repercussions on other aspects, eg the heat resistance of lactic acid bacteria.

Organic acids are the major products of sugar catabolism. It is important to note that it is the molecular, or non-ionized, form of these acids which exerts the greatest inhibition. Technological advantages could arise from these observations.

\section{ACKNOWLEDGMENTS}

We would like to express our gratitude to $\mathrm{Dr} J \mathrm{P}$ Accolas for his insight and guidance in the critical reading of the manuscript. We also thank $J$ Galle for preparing the figures.

\section{REFERENCES}

Accolas JP, Bloquel R, Didienne R, Régnier J (1977) Propriétés acidifiantes des bactéries lactiques thermophiles en relation avec la fabrication du yoghourt. Lait 57, 1-23

Accolas JP, Hemme D, Desmazeaud MJ, Vassal L, Bouillanne C, Veaux M (1980) Les levains lactiques thermophiles : propriétés et comportement en technologie laitière. Une revue. Lait $60,487-524$
Adams MR, Hall CJ (1988) Growth inhibition of food borne pathogens by lactic and acetic acids and their mixtures. Int J Food Sci Technol 23, 287-292

Ananthaswamy HN, Eisenstark A (1977) Repair of hydrogen peroxide-induced single-strand breaks in Escherichia coli deoxyribonucleic acid. J Bacteriol 130, 187-191

Anders RF, Hogg DM, Jago GR (1970) Formation of hydrogen peroxide by group $N$ streptococci and its effect on their growth and metabolism. Appl Microbiol 19, 608-612

Archibald FS, Fridovich I (1981) Manganese, superoxide dismutase and oxygen tolerance in some lactic acid bacteria. J Bacteriol 146, 928-936

Asperger H (1986) Wirkungen von Milchsäurebakterien auf andere mikroorganismen. Oesterr Milchwirts 41, suppl 1 to issue 4, 1-22

Aune TM, Thomas EL (1977) Accumulation of hypothiocyanite ion during peroxidasecatalyzed oxidation of thiocyanate ion. Eur $J$ Biochem 80, 209-214

Björck L, Rosen CG, Marshall VM, Reiter B (1975) Antibacterial activity of the lactoperoxidase system in milk against pseudomonads and other Gram-negative bacteria. Appl Microbiol 30, 199-204

Blocher JC, Busta FF (1983) Bacterial spore resistance to acids. Food Technol 37 , nov, 87 99

Britton L, Malinowski DP, Fridovitch I (1978) Superoxide dismutase and oxygen metabolism in Streptococcus faecalis and comparisons with other organisms. J Bacteriol 134, 229236

Byczkowski J, Gessner T (1988) Biological role of superoxide ion-radical. Int $J$ Biochem 20, 569-580

Chung KC, Goepfert JM (1970) Growth of Salmonella at low pH. J Food Sci 35, 326-328

Cogan TM (1980) Les levains lactiques mésophiles. Une revue. Lait 60, 397-425

Cogan JF, Walsh D, Condon S (1989) Impact of aeration on the metabolic end-products formed from glucose and galactose by Streptococcus lactis. J Appl Bacteriol 66, 77-84

Condon S (1983) Aerobic metabolism of lactic acid bacteria. Ir J Food Sci Technol 7, 15-25 
Condon S (1987) Responses of lactic acid bacteria to oxygen. FEMS Microbiol Rev 46, 269-280

Dahiya RS, Speck ML (1968) Hydrogen peroxide formation by lactobacilli and its effect on Staphylococcus aureus. J Dairy Sci 51, 1568-1572

Dahl TA, Midden WR, Hartman PE (1989) Comparison of killing of Gram-negative and Gram-positive bacteria by pure singlet oxygen. J Bacteriol 171, 2188-2194

Daly C, Sandine WE, Elliker PR (1972) Interactions of food starter cultures and food borne pathogens: Streptococcus diacetylactis versus food pathogens. J Milk Food Technol 35 , 349-357

Daniels HJ (1966) Inhibition of growth of Pseudomonas denitrificans by amino acids. Can J Microbiol 12, 1095-1098

Di Mascio P, Wefers $H$, Do-Thi HP, Lafleur MVM, Sies H (1989) Singlet molecular oxygen causes loss of biological activity in plasmid and bacteriophage DNA and induces single-strand breaks. Biochim Biophys Acta 1007, 151-157

Egyud LG (1967) Studies on cell division, the effect of aldehydes, ketons, and $\alpha$-ketoaldehydes on the proliferation of Escherichia coli. Curr Med Biol 1, 14-20

Freese EG, Gerson J, Taber H, Rhaese HJ, Freese $E$ (1967) Inactivating DNA alterations induced by peroxides and peroxideproducing agents. Mutat Res 4, 517-531

Gilliland SE (1985) Concentrated starter cultures. In: Bacterial Starter Cultures for Food (Gilliland SE, ed) CRC Press, 145-157

Gilliland SE, Speck ML (1968) D-Leucine as an auto-inhibitor of lactic streptococci. J Dairy Sci 51, 1573-1578

Gothefors L, Marklund S (1975) Lactoperoxidase activity in human milk and in saliva of newborn infants. Infect Immun 11, 12101215

Gray ML, Killinger AH (1966) Listeria monocytogenes and Listeria infections. Bacteriol Rev 30, 309-382

Gregory EM, Fridovich I (1974) Oxygen metabolism in Lactobacillus plantarum. J Bacteriol 117, 166-169

Hanström L, Johansson A, Carlsson J (1983) Lactoperoxidase and thiocyanate protect cul- tured mammalian cells against hydrogen peroxide toxicity. Med Biol 61, 268-274

Harley JB, Santangelo GM, Rasmussen H, Goldfine H (1978) Dependence of Escherichia coli hyperbaric oxygen toxicity on the lipid acyl chain composition. J Bacteriol 134, 808-820

Haugaard N (1968) Cellular mechanisms of oxygen toxicity. Physiol Rev 48, 311-373

Jay JM (1982) Antimicrobial activity of diacetyl. Appl Environ Microbiol 44, 525-532

Juillard V, Spinnler HE, Desmazeaud MJ, Boquien CY (1987) Phenomènes de coopération et d'inhibition entre les bactéries lactiques utilisées en industrie laitière. Lait 67, 149-172

Kashket ER (1987) Bioenergetics of lactic acid bacteria: cytoplasmic $\mathrm{pH}$ and osmotolerance. FEMS Microbiol Rev 46, 233-244

Kleter G, Lammers WL, Vos EA (1984) The influence of $\mathrm{pH}$ and concentration of lactic acid and $\mathrm{NaCl}$ on the growth of Clostridum tyrobutyricum in cheese. Neth Milk Dairy J 38, 3141

Kong S, Davison AJ (1980) The role of interactions between $\mathrm{O}_{2}, \mathrm{H}_{2}, \mathrm{OH}, e^{-}$and $\mathrm{O}_{2}$ - in free radical damage to biological systems. Arch Biochem Biophys 204, 13-29

Konings WN (1985) Generation of metabolic energy by end product efflux. Trends Biochem Sci $10,317-319$

Konings WN, Otto R (1983) Energy transduction and solute transport in streptococci. Antonie Leeuwenhoek 49, 247-257

Kono Y, Fridovich I (1983) Isolation and characterization of the pseudocatalase of Lactobacillus plantarum. J Biol Chem 258, 60156019

Kulshrestha DC, Marth EH (1975) Some volatile and nonvolatile compounds associated with milk and their effects on certain bacteria. A review. J Milk Food Technol 38, 604-620

Law BA, John P (1981) Effect of the lactoperoxidase bactericidal system on the formation of the electrico-chemical proton gradient in E coli. FEMS Microbiol Lett 10, 67-70

Marshall WME, Reiter B (1980) Comparison of the antibacterial activity of the hypothiocyanite anion towards Streptococcus lactis and Escherichia coli. J Gen Microbiol 120, 513516 
Morgan RB, Christman MF, Jacobson FS, Storz G, Ames BN (1986) Hydrogen peroxideinducible proteins in Salmonella typhimurium overlap with heat shock and other stress proteins. Proc Natl Acad Sci USA 83, 8059-8063

Murphy MG, Condon S (1984) Comparison of aerobic and anaerobic growth of LactobacilIus plantarum in a glucose medium. Arch Microbiol $138,49-53$

Oram JD, Reiter B (1966) The inhibition of streptococci by lactoperoxidase, thiocyanate and hydrogen peroxide. Biochem J 100, 373-381

Price RJ, Lee JS (1970) Inhibition of Pseudomonas species by hydrogen peroxide producing lactobacilli. J Milk Food Technol 33, 13-18

Pruitt KM, Reiter B (1985) Biochemistry of peroxidase system: antimicrobial effects. In: The Lactoperoxidase System (Pruitt KM, Tenovuo J, eds) Immunology Series, M Dekker Inc, NY, vol 27, 143-178

Pruitt KM, Tenovuo J, Andrews RW, McKane T (1982) Lactoperoxidase-catalysed oxidation of thiocyanate: polarographic study of the oxidation products. Biochemistry 21, 562-567

Purdy MA, Tenovuo J, Pruitt KM, White WE (1983) Effect of growth phase and cell envelope structure on susceptibility of Salmonella typhimurium to the lactoperoxidase thiocyanate hydrogen peroxide system. Infect $\mathrm{Im}$ mun 39, 1187-1195

Reiter B (1985) The lactoperoxydase system of bovine milk. In: The Lactoperoxidase System (Pruitt KM, Tenovuo J, eds) Immunology Series, M Dekker Inc, NY, vol 27, 123-141

Reiter B, Härnulv G (1984) Lactoperoxidase antibacterial system: natural occurrence, biological functions and practical applications. $J$ Food Prot 47, 724-732

Rolfe RD, Hentges DJ, Campbell BJ, Barett JT (1978) Factors related to the oxygen tolerance of anaerobic bacteria. Appl Environ Microbiol 36, 306-313

Siragusa GR, Johnson MG (1989) Inhibition of Listeria monocytogenes growth by the lacto- peroxidase-thiocyanate- $\mathrm{H}_{2} \mathrm{O}_{2}$ antimicrobial system. Appl Environ Microbiol 55, 28022805

Smart JB, Thomas TD (1987) Effect of oxygen on lactose metabolism in lactic streptococci. Appl Environ Microbiol 53, 533-541

Stadhouders J, Langeveld LPM (1966) The microflora of the surface of cheese. Factors affecting its composition. 17th Int Dairy Congr, Vol D, 577-584

Steele WF, Morrison M (1969) Antistreptococcal activity of lactoperoxidase. J Bacteriol 97, 635-639

Teeri AE (1954) Effect of D-amino acids on growth of lactobacilli. J Bacteriol 67, 686-689

Ten Brink B, Konings WN (1982) Electrochemical proton gradient and lactate concentration gradient in Streptococcus cremoris cells grown in batch cultures. J Bacteriol 152, 682686

Thomas EL (1985) Bacterial hydrogen peroxide production. In: The Lactoperoxidase System (Pruitt KM, Tenovuo J, eds) Immunological Series, M Dekker Inc, NY, vol 27, 179-202.

Thomas EL, Aune TM (1978) Lactoperoxidase, peroxide, thiocyanate antimicrobial system: correlation of sulfhydryl oxidation with antimicrobial action. Infect Immun 20, 456-463

Whittenbury R (1964) Hydrogen peroxide formation and catalase activity in the lactic acid bacteria. J Gen Microbiol 35, 13-26

Wong HC, Chen YL (1988) Effects of lactic acid bacteria and organic acids on growth and germination of Bacillus cereus. Appl Environ Microbiol 54, 2179-2184

Wright RC, Tramer J (1958) Factors influencing the activity of cheese starters. The role of milk peroxidase. J Dairy Res 25, 104-118

Yousten AA, Johnson JL, Salin M (1975) Oxygen metabolism of catalase negative and catalase-positive strains of Lactobacillus plantarum. J Bacteriol 123, 242-247 